By ROBERT B. DOWNS

\title{
Are College and University Librarians Academic?
}

Dr. Downs is director, University of Illinois Library and Library School.

$\mathrm{O}$ NE OF THE MOST time-honored clichés tossed off by college and university presidents and other professional educators is this one: "The library is the heart of the institution." In that phrase, there is expressed an ideal situation, almost universally recognized as a desirable goal, but all too infrequently realized in practice. It is a common occurrence for the presidents whom I quoted to turn around, immediately after making their library speech, and place a new gymnasium or enlarged stadium ahead of an adequate library in their building programs. It may well be, of course, that both are needed, but in establishing priorities, it is a question of whether to emphasize the heart and brain or the muscles of an institution. Anyway, college and university presidents are in a tough spot when confronted by athletic-minded alumni who have never read a book, and they have my full sympathy, as they are caught upon the horns of a dilemma, and called upon to make such difficult choices.

But let us examine a little further this old saw, "The library is the heart of the institution." We have been hearing this expression since we first entered library schools. It flatters our vanity, makes us feel important, gives us a sense of being indispensable, and is altogether gratifying to our ears. Perhaps we should do a little self-analysis, however, to determine how much actual ground there is for a statement, the truth of which most of us have simply taken for granted. Are libraries really essential to the college or university's educational program? We could gather impressive statistics and expert testimony from many quarters supporting the point of view that much teaching and research activity would be crippled, if not brought to a complete halt, by the lack of libraries. Under modern conditions, it is inconceivable that scholars could be developed and trained, and carry on their work, without libraries. Even those subject fields which depend primarily on laboratories must support expensive libraries and elaborate abstracting and indexing services to help them avoid repetition of effort and to serve as points of departure for new scientific advances. It can be fairly stated that an adequate library is not only the basis of all teaching and study, but is an essential condition for research, without which additions are unlikely to be made to the sum of human knowledge.

One somewhat subjective measure we can use in evaluating the place of the library is to look at the quality of the institution as a whole. It has been my observation that, almost invariably, a strong college or university is characterized by a strong, well-supported library, while, to reverse the coin, weak libraries typify mediocre educational institutions.

Now, assuming that we accept as proven and true the presidential cliche designating the library as a fundamental organ, i.e., the heart, how can we judge the health of this important member, without which the rest 
of the body stops functioning? There are, of course, standard criteria, such as the size and nature of the book collection, adequacy of building and other physical facilities, the library budget in relation to total educational expenditures, and the number of staff members. All of these are indicative and useful. To my mind, however, no criterion is more reliable than the quality and status of the library staff, and here, at last, I come to the main point of this paper..

Just as we can judge the college or university in terms of its library, so we can judge the library in terms of its staff. If the librarians are recognized as an integral part of the academic ranks, if they are a vital group in the educational process, with high qualifications for appointment, and all the rights and privileges of other academic employees, we can feel confident that the library will rank high in all-round effectiveness. On the other hand, if the professional library personnel are in some nondescript category, without clearly defined status, with no institutional understanding of the contributions which they can make to the educational program, and placed outside, or made ineligible for, the usual academic perquisites and prerogatives, we can be equally certain that the library is inferior, falling far below its potentialities. There is the difference. The institution can pay its money and take its choice.

Before attempting to answer the question in the title of my paper, "Are College and University Librarians Academic?", let's examine the nature of an academic staff in a present-day university, and because I am best acquainted with the University of Illinois organization, I will take that institution as an example. As revised by the Board of Trustees about ten years ago, the University statutes define the word "academic" as follows:

The academic staff which conducts the educational program shall consist of the teaching staff, the research staff, the extension staff, deans, directors of educational departments, high school visitors, librarians, and such other members of the staff as are designated by the president.

Please take particular note of the breadth of this definition. Vanished is the old tradition that only the person who stands up in front of a class room full of students belongs in the academic or faculty classification. Instead, we find included, for example, farm and home demonstration agents; research workers whose entire time is spent in laboratories and libraries, and who practically never come into direct contact with students; editors and other university press staff; radio and television personnel; the numerous deans and assistant deans of students; audio-visual specialists; student health service doctors; athletic coaches; the university legal representative and . his staff; student counselors; and, finally, professional librarians. Where does this leave the hackneyed, oft-repeated argument of those who oppose academic status for librarians, i.e., the argument that librarians are not properly classifiable as academic, because most of them engage in no formal classroom instruction?

As a matter of fact, so diverse and so complex have the activities of the modern university become that a definition of academic staff limited to the classroom teachers would be ridiculously narrow. Instead, the trend is to consider as academic everyone contributing directly and substantially to the educational and research activities of the institution. The question might then logically be asked: Is the participation of librarians in the educational program sufficiently direct and substantial to justify their inclusion in the academic classification? A complete answer would require a minute analysis of the educational preparation, duties, functions, and responsibilities of librarians, and these are fully as varied in nature as any other large segment of a university staff. Let's examine first the kind of 
educational background expected and required of librarians.

There are now four library schools offering the doctor's degree in librarianship: Chicago, Columbia, Illinois, and Michigan, and the number of librarians holding the doctorate is steadily increasing. California is considering a doctoral program. Practically all other accredited library schools are likewise set up at the graduate level, and offering master's degrees. In addition, for many departmental, divisional, and other specialized subject positions in libraries, not only library school preparation is essential but also knowledge of such fields as chemistry, biological sciences, agriculture, engineering, mathematics, medicine, law, fine arts, music, history, education, business, and journalism. It is quite common, therefore, to find in these positions persons with advanced training both in library science and in subject areas. In these instances, more is expected of the librarian in the way of educational background than of the typical classroom instructor, who is called upon to be an expert in one sphere only. On the University of Illinois library staff, for example, are persons with graduate degrees in bacteriology, bio-chemistry, chemistry, zoology, anthropology, physics, and mathematics, among the sciences; classical languages, philology, French, Spanish, English, speech, fine arts, and music, in the humanities; and history, political science, education, law and physical education, among the social sciences. All these individuals hold, in addition, of course, degrees in library science.

So much for preparation. How about the work itself? Look, there, at the technical processes, perhaps the least understood by laymen of all library operations. A top-notch acquisitions librarian, or a firstclass subject cataloger and classifier must know far more than the outside covers of books to perform competently. In the catalog and other technical divisions of the
Library of Congress, the New York Public Library, and large university libraries, for instance, one would find gathered linguists and subject experts whose erudition would stand comparison with most other university faculty members. Furthermore, everything they know will be needed, sooner or later-so demanding is the modern research library and its collections.

One could go on to other groups of librarians and find similar situations. The case of departmental librarians in subject fields has been mentioned. These librarians require a comprehensive familiarity with books, journals, pamphlets, and unpublished data in their specialties. Without their thorough acquaintance with the available literature and tools, much promising research would die on the vine. Faculty members and graduate students find their aid and advice indispensable. Another group performing a similar, but more generalized, service are the reference librarians, who are to libraries what the family doctor or general practitioner is to medicine, in that, they need to know something about everything. Of all people in our time, they come closest to the Renaissance ideal of the universal man, who took all knowledge to be his province and tried to absorb the whole. The fact that success is never quite reached is immaterial. What an able reference librarian can accomplish is impressive enough, and he, or more frequently she, is heavily relied upon by everyone engaged in serious study or research.

The whole matter boils down, it seems to me, to the question of whether librarians are entitled to hold up their heads in a community of scholars. I believe the answer is yes, because librarians are contributing in fundamental fashion, through developing and making available resources for study and research, to the primary purposes for which colleges and universities were founded. The classroom instructor, the research scholar, the librarian, and other 
members of the academic staff together form a great team, and each person on the team has a vital part to play. None of them is more important or less important than the others, for the omission of any one would alter the very character of an educational institution.

As we survey the country to note the present attitude toward, and prevailing practices regarding academic rank for librarians, we find quite a mixed picture. The situation has not changed materially since the excellent study made by Frank Lundy and published in $C$ E $R L$ in I95I. No uniform practice has evolved, though as Mr. Lundy reported, "the educational function of the library and the academic responsibilities of its professional staff appear to be clearly recognized in most of the 35 institutions studied." It was noted that, "in I4 institutions . . . the identification of the library professional staff with the teaching and research staff, rather than with the administrative and clerical staff, has been firmly established," usually with the assignment of appropriate academic ranks. Of the remainder, eight institutions had accepted librarians into the faculty with various reservations and limitations; seven were concerned with the problem, but had reached no solution; and seven others had come to the conclusion that the assignment of academic rank was not the best method for recognizing the work of professional librarians. ${ }^{1}$

It is the attitude of this last group, those who are skeptical of the applicability of academic rank to librarians, which I think should be viewed with concern. When some of the leading university librarians of the country have so little confidence in the contributions which they and their colleagues are making to higher education that they doubt whether library staffs should be ranked with the faculty,

1 Lundy, Frank A., "Faculty Rank of Professional Librarians," College and Research Libraries, I 2:1 I-I9, I 09-22, January-April, I 95 I, it is not only discouraging but downright appalling. It is an ironic fact, however, that these same chief librarians are willing to accept and usually insist upon academic rank for themselves. Whether consistency is a jewel or the bane of small minds, strict logic would lead them to reject the professorships which they proudly list in "Who's Who" sketches.

But, say these individuals, there are alternatives to faculty rank. True, and let's see what they are. A few universities attempt to meet the problem by setting up the library staff in a separate professional category, on the theory, apparently, that librarians are so unlike any other group in the institution, they do not fit any established classification. In other instances, librarians are considered administrative employees, and listed with the business office, registrar's office, physical plant office, and similar nonacademic staff members. Several large universities with which I am acquainted assign librarians to so-called "equivalent ranks," but not actually identical ranks with those of faculty members - a scheme which gives the librarians involved a very hazy status indeed. All of these plans, it should be noted, are compromises, and therefore fully satisfactory to no one. Even a compromise is preferable, however, to the confused situation which is found in the numerous colleges and universities that fail to define any place for librarians in their organizations, letting them fall, for the most part, in the nebulous region between clerical and teaching staffs.

For institutions supported by federal, state, and municipal funds, there is still another substitute-civil service. In regard to this, I am of the same state of mind as a writer some time ago on the federal civil service system, who, after examining the multiple defects of civil service, entitled his article, "Let's Go Back to the Spoils System!" I imagine the Eisenhower administration is feeling the same way about 
it these days as it goes about trying to make places for deserving Republicans by unfreezing the thousands of loyal Democrats frozen into civil service protection by the previous administration.

Seriously, however, I am convinced that civil service is an almost unmitigated curse when applied to university library staffs. All too frequently, it is used for the protection of the mediocre and inefficient, and reduces ambition and initiative. The library is handicapped in finding the best qualified persons for positions, because of restrictive residence and other special requirements, and examinations. The acute shortage of professional librarians which has prevailed for the past decade or more, and is likely to continue for some years into the future, means that innumerable job opportunities are open to good people who do not have to submit to civil service examinations. This fact handicaps the library operating under civil service in attracting the strongest candidates. Another fault inherent in a civil service organization is the transfer of many vital elements of control of the library staff from the library administration to civil service officers. Such aspects as salary scales, vacations, holidays, sick leaves, leaves of absence, hours of work, retirement, and working conditions in general, are likely to be dictated by civil service regulations, and the librarian has little or no voice in these matters. Perhaps the most important consideration of all is that, in the academic atmosphere, professional librarians feel stigmatized by being classified as civil service workers, for ordinarily they alone among all university employees primarily engaged in academic activities are so designated.

My conclusion is that civil service and all the other suggested alternatives to clearcut academic status for librarians in colleges and universities are snares and delusions, containing fundamental weaknesses which prevent any one of them from being anything except an ambiguous and unsatisfactory expedient.

On the assumption that the work which librarians do justifies grouping them with the teaching faculty, what specific advantages does academic status carry for them? In other words, is it chiefly a matter of prestige, to help librarians avoid inferiority complexes and to make them eligible to attend faculty meetings, or is it worth striving for for other reasons? The situation varies from one institution to another, but in almost all cases the librarians stand to gain materially by merging with the rest of the academic staff. In such matters as salary standards, vacations and holidays, sick leaves, sabbaticals, and retirement, the provisions for the faculty are likely to be more liberal than for non-faculty members. This condition may change eventually through the efforts of labor unions, but as far ahead as can be seen now, I would be willing to throw in my lot and sink or swim with the faculty.

There should, of course, be no privileges without some corresponding responsibilities for librarians. If we are going to fight for and get academic recognition, we must do our part to merit it. There are various ways in which this can be done. One of our first tasks, I think, is to achieve a clear distinction and separation between clerical and professional duties in libraries. The most telling objection to the acceptance of librarians into academic circles is that in perhaps a majority of our libraries there are too many routine, non-professional jobs being carried on by so-called professional staff members. It is difficult for professional librarians to defend such assignments as checking in current periodicals, charging out books across a loan desk, filing catalog cards, typing orders, reading book shelves, keeping financial records, binding pamphlets, and all the other necessary, but strictly sub-professional, activities that go on in libraries. One reliable yardstick for 
determining whether an undue proportion of non-professional work is being done by librarians is to compare the ratio of clerical workers to the total staff. If more than 50 per cent, indeed some experts in administration say if more than one-third, of the entire staff is composed of professionals, the probabilities are that they are performing a substantial amount of clerical routines, and at the same time neglecting opportunities to make important and useful contributions of a professional character. The ideal exact ratio may be open to question, and can perhaps best be determined by detailed analyses of positions.

As a corollary to the point I have just made, librarians can further establish their claim to academic standing by positive contributions to the institution's educational program. The library ought to be made a genuine teaching agency through such devices as general courses on the use of books and libraries, through bibliographical instruction to students at all levels, through courses on the literature of special subject fields, through appropriate participation in courses in other departments, through publications instructing students in the utilization of the library's resources, by bookreviewing programs, by well arranged and pertinent exhibitions of library materials, and by constant aid to individual research and study projects. A library which conducts these types of activities need have no concern about proper recognition of its professional staff.

There are other directions, also, in which librarians need to exert themselves in order fully to establish their place in the academic world. One is through better educational preparation. We ought to have more graduate degrees, both at the doctoral and master's level, represented on our staff, in subject fields, as well as in library science. Like the teaching profession, librarianship is becoming increasingly a career for specialists, and our requirements are exceedingly diverse. In the future, college and university librarians will undoubtedly be called upon to have academic preparation as thorough and as advanced as their colleagues in other fields.

Other ways to achieve academic respectability are to write for the professional journals, to carry on needed research in library science, and to help strengthen library associations by active participation in them. These things are expected of faculty members in all disciplines. If librarianship is a true profession, and I am persuaded that it is, then librarians can do no less. In recent years, the quality and quantity of library professional literature have shown a vast improvement. Librarians know more about scientific research methods, and this is reflected in their writings. The same factors are observable in the work of our professional associations. All the evidence, I submit, points toward the fact that librarianship as a profession is rapidly coming of age.

Perhaps no summary or conclusion is necessary for these remarks. I am frank to admit that my approach to the subject is somewhat partisan. Nevertheless, I have been aware of the problem of the librarian's status for thirty years, and during much of that period I have been directly concerned with it as a university library administrator. It is on the basis of that experience, observation, and study that I have become convinced that compromises, expedients, and substitutes are undesirable, and a direct, straightforward solution is ultimately the best. 